\title{
Insecticide resistance management against thrips (Thysanoptera: Thripidae) on onion in the central Rift Valley of Ethiopia
}

\author{
Belete Negash ${ }^{1} \cdot$ Ferdu Azerefegn ${ }^{1} \cdot$ Gashawbeza Ayalew $^{2}$ \\ Received: 17 April 2019 / Accepted: 18 February 2020 / Published online: 2 March 2020 \\ (C) The Author(s) 2020
}

\begin{abstract}
Two field experiments were conducted in the Central Rift Valley of Ethiopia in the hot and cool dry seasons of 2016/2017 with the objective to develop an insecticide resistance management program on thrips infesting onion. The first experiment dealt with the evaluation of four different insecticides namely profenofos, $\lambda$-cyhalothrin, imidacloprid, and spinetoram in different sequences on thrips population and their effect on yield. The second experiment examined the effect of admixing the surfactant organosilicone with imidacloprid, spinetoram and dimethoate. A Randomized Complete Block Design with three replications was used for both experiments. Data on number of thrips, bulb yield and economic returns were collected. The insecticide imidacloprid and spinetoram resulted in fewer numbers of thrips and higher yields than profenofos and $\lambda$-cyhalothrin. Application of the more effective insecticides when the thrips population was high followed by less effective insecticides resulted in better control and higher economic return. Surfactant added insecticides gave a fewer numbers of thrips and higher yields than the corresponding insecticides applied without surfactant. The sequential application of spinetoram and imidacloprid with less effective $\lambda$-cyhalothrin and profenofos by mixing with adjuvant are recommended for thrips control as an integral component of thrips management in the Central Rift Valley of Ethiopia.
\end{abstract}

Keywords Thrips $\cdot$ Resistance $\cdot$ Management $\cdot$ Insecticides $\cdot$ Rotation $\cdot$ Surfactant

\section{Introduction}

Onion (Allium cepa L.) is a widely grown vegetable by small and large-scale farmers in Ethiopia covering an area of $48,443.36$ ha with the total production of 374,704 tons (CSA 2016). The national average productivity of onion in Ethiopia is $7.734 \mathrm{t} \mathrm{ha}^{-1}$ (CSA 2016) which is low compared to the world average of $19.49 \mathrm{t} \mathrm{ha}^{-1}$ (FAOSTAT 2012). This low productivity could be attributed to poor agronomic practices and pests damage (Tadele and Amin 2014). Onion thrips,

Belete Negash

belete22@gmail.com

Ferdu Azerefegn

azeref@gmail.com

Gashawbeza Ayalew

gashawbeza@yahoo.com

1 College of Agriculture, Hawassa University, Hawassa, Ethiopia

2 Ethiopian Institute of Agricultural Research, Melkassa Research Center, Adama, Ethiopia
Thrips tabaci Lind. (Thysanoptera: Thripidae) is considered as the most economically important pests of onion worldwide (Gachu et al. 2012). Thrips are major pests in all oniongrowing areas of Ethiopia and can routinely reduce bulb yields by $23-85 \%$ (Tadele and Mulugeta 2014). Bekele et al. (2006) reported 10 to $85 \%$ onion bulb yield losses due to onion thrips at Upper Awash Agro Industry areas in Central Ethiopia.

The use of insecticides is the most common management tactic for onion thrips infestations in Ethiopia as it is elsewhere (Reitz 2014; Gill et al. 2015). Indiscriminate application of insecticides against onion thrips in onion is a common practice in the Rift Valley of Ethiopia (Banchiamlak et al. 2012). Such misuse of insecticides could lead to the development of insecticide resistant biotypes. Many targeted pests species in the world have developed resistance due to intensive use of pesticides (Tabashnik et al. 2009). Moreover, most insecticides are ineffective because a large number of thrips are protected between the inner leaves of the onion plant and the pupal stage is spent in the soil (Shelton et al. 2003, 2006; Nault and Shelton 2010).

Thrips can rapidly develop resistance to insecticides which results in the rapid loss of effectiveness of new insecticides 
(Reitz 2014). Insecticides resistance has been documented in a number of chemical classes, including the organochlorines, organophosphates, carbamates, pyrethroids and spinosyns (Bielza et al. 2007; Herron et al. 2008; Nault et al. 2013). Resistance of onion thrips to some synthetic insecticides is suspected in Ethiopia because many of the earlier registered products for control of the pests are losing control efficacy (Tadele and Amin 2014).

Several insecticides from different classes are registered for control of thrips on onion in Ethiopia (MoANR 2017). Sustainable use of these insecticides entails a pesticide resistance management program, which can be achieved, among others, by rotational application from different insecticide classes (Gill and Garg 2014). Another important tactic to improve pesticide efficacy in thrips control on onion, prevent or slow down insect resistance to insecticides is the use of a penetrating surfactant. Surfactants could improve deposition of sprays applied to the onion leaves and the efficacy of insecticides against onion thrips (Gangwar et al. 2016). Inclusion of a penetrating surfactant is critical for improving the efficacy of insecticides that have systemic and translaminar movement within onion plants to control onion thrips (Nault et al. 2013).

Insecticides use for thrips control will continue, but this strategy must be used carefully and in a manner that will prevent or slow down the ability of thrips to develop resistance (Nault et al. 2013). In Ethiopia, there has not been any known comprehensive study on the effects of penetrating surfactant to insecticide efficacy and rotational application of insecticides for thrips control. Thus, this research was designed to evaluate effects of rotational application of insecticides and use of surfactant against thrips on onion.

\section{Materials and methods}

\section{Effect of rotational application of insecticides}

The efficacy of rotational application of four selected insecticides in different sequences against thrips on onion was conducted at Melkassa Agricultural Research Center, East Showa, Ethiopia. Melkassa is located at $8^{0} 24^{\prime} \mathrm{N}$ and $30^{\circ} 21^{\prime}$ $E$ at elevation of 1550 m.a.s.l. The area is characterized by low and erratic rainfall with an average of $771 \mathrm{~mm}$ rainfall per year over $80 \%$ of which falls between April and October, with a peak in July and August. The soil is mainly sandy with pH of 6.9-7.9 and the mean air temperature is $21^{\circ} \mathrm{c}$ (Desalegne and Shimeles 2003).

The experiment was conducted for two seasons during the cool dry period (October 2016-February 2017) and hot dry period (March 2017-June 2017). Four selected insecticides each representing a specific insecticide class and registered for thrips control on onion in Ethiopia were applied sole and in rotation using different sequences (Table 1). The insecticides were profenofos (Organophosphates), imidacloprid (Neonicotinoids), $\lambda$-cyhalothrin (Pyrethoids) and spinetoram (Spinosyn). These insecticides are widely used by vegetable growers in the Central Rift Valley of Ethiopia (CRV). The experiment was laid in a Randomized Complete Block Design (RCBD) with three replications. Insecticides treatments were applied using a manually operated knapsack sprayer of 15-Liter capacity. They were applied weekly for 8 weeks and the first application was made 12 December in cool dry and 30 March in hot dry periods, when thrips populations reached five per plant from a random sample of ten plants.

\section{Effect of surfactant on efficacy of selected insecticides}

The effects of a penetrating surfactant organosilicone (Silwet gold) on insecticides efficacy against thrips on onion was evaluated in both the hot dry period (March 2016-June 2016) and cool dry period (October 2016 - February 2017) as described in the experiment on rotational application. The experiment consisted of eight treatments; imidacloprid (Con-fidence $350 \mathrm{SC}$ applied at $400 \mathrm{ml} / \mathrm{ha}$ ), spinetoram (Radiant $120 \mathrm{SC}$ applied at $130 \mathrm{ml} / \mathrm{ha}$ ) and dimethoate (Agro-Thoate $40 \%$ EC applied at $1 \mathrm{~L} / \mathrm{ha}$ ) with and without surfactant (Silwet gold $(0.1 \% \mathrm{v} / \mathrm{v})$. Untreated check and application of surfactant alone were included for comparison. The tested insecticides were selected based on their mode of action (systemic and translaminar). The experiment was laid out in a Randomized Complete Block Design (RCBD) with three replications. Treatments were applied weekly for 7 weeks using manually operated 15-Liter knapsack sprayer. The first application was made when thrips populations reached five per plant from a random sample of ten plants.

\section{Agronomic practices}

Onion seedlings of Bombay red variety was raised on nursery bed and transplanted at 2-3 leaf stage. Each plot was $9 \mathrm{~m}^{2}$ $(3 \mathrm{~m} \times 3 \mathrm{~m})$ with five double rows spaced $0.2 \mathrm{~m}$ apart. Spaces between blocks, plots, and plants were $1.5 \mathrm{~m}, 1.5 \mathrm{~m}$, and $0.1 \mathrm{~m}$, respectively. The experimental fields were irrigated twice per week for the first 3 weeks after transplanting and weekly thereafter. The fields were fertilized with Diammonium phosphate (DAP) and urea at the rate of $200 \mathrm{~kg}$ and $150 \mathrm{~kg}$ per hectare, respectively. The DAP was applied during transplanting and urea was applied split in two halves; the first half was applied during transplanting and the remaining half 30 days after transplanting. Weeding was carried out as required. 
Table 1 Details of treatments in the insecticide rotation experiment at MARC, 2016/17

\begin{tabular}{|c|c|c|c|c|c|}
\hline \multirow[t]{2}{*}{ No } & \multirow[t]{2}{*}{ Treatment } & \multicolumn{4}{|c|}{ Application period } \\
\hline & & Weeks 1 and 2 & Weeks 3 and 4 & Weeks 5 and 6 & Weeks 7 and 8 \\
\hline 1 & I- I-I-I & imidacloprid & Imidacloprid & Imidacloprid & imidacloprid \\
\hline 2 & L-L-L-L & $\lambda$-cyhalothrin & $\lambda$-cyhalothrin & $\lambda$-cyhalothrin & $\lambda$-cyhalothrin \\
\hline 3 & P-P-P-P & profenofos & Profenofos & profenofos & profenofos \\
\hline 4 & $\mathrm{~S}-\mathrm{S}-\mathrm{S}-\mathrm{S}$ & spinetoram & Spinetoram & spinetoram & spinetoram \\
\hline 5 & L- S- P- I & $\lambda$-cyhalothrin & Spinetoram & profenofos & imidacloprid \\
\hline 6 & I- P-S- L & imidacloprid & Profenofos & spinetoram & $\lambda$-cyhalothrin \\
\hline 7 & $\mathrm{I}-\mathrm{S}-\mathrm{L}-\mathrm{p}$ & imidacloprid & Spinetoram & $\lambda$-cyhalothrin & profenofos \\
\hline 8 & P-L- I- S & profenofos & $\lambda$-cyhalothrin & imidacloprid & spinetoram \\
\hline 9 & S- I -P -L & spinetoram & imidacloprid & profenofos & $\lambda$-cyhalothrin \\
\hline 10 & Untreated & untreated check & untreated check & untreated check & untreated check \\
\hline
\end{tabular}

$\mathrm{L}=\lambda$-cyhalothrin (Karate $5 \mathrm{EC}$ at $300 \mathrm{ml} / \mathrm{ha}$ ), I = imidacloprid (Con-fidence $350 \mathrm{SC}$ at $400 \mathrm{ml} / \mathrm{ha}$ ), $\mathrm{P}=$ profenofos $72 \% \mathrm{EC}$ (Girgit-Plus at $600 \mathrm{ml} / \mathrm{ha}$ ), and $\mathrm{S}=$ spinetoram $($ Radiant $120 \mathrm{SC}$ at $130 \mathrm{ml} / \mathrm{ha})$

\section{Data collection and analysis}

\section{Data collection}

The post spray data were taken at seven-day interval prior to the next application. Thrips population was counted on five randomly selected plants from the central rows of each plot by visually examining the entire plant parts. At maturity, onion bulbs were harvested from the middle three double rows in each plot and then sorted out into marketable and unmarketable bulbs. Healthy bulb weighing between 20 and $160 \mathrm{~g}$ was considered marketable (Desalegne and Shimeles 2003).

\section{Statistical analysis}

Thrips count data were square root $(\sqrt{ } \mathrm{x}+0.5)$ transformed before analysis to stabilize the variance and normalize the data. Thrips population and yield were analyzed using the general linear model of statistical analysis using SAS software (SAS Institute 2003). When significant differences were observed in the ANOVA, mean separation was performed using Student-Newman-Keuls (SNK) test.

\section{Economic analysis}

The relative economic returns of the treatments were calculated by subtracting the cost of insecticides and their application cost from the gross return. The price of onion bulb was estimated based on the farm gate price at US\$ 350.87 per ton. The application cost in the first experiment was estimated at USD 140.32 per ha (32 mandays per ha; 4.385 USD per manday) and in the second season at 122.78 USD (28 mandays per ha; 4.385 per manday). The price of imidacloprid, profenofos, $\lambda$ cyhalothrin, spinetoram, dimethoate and organosilicone per liter were estimated at USD 35.08, 35.83, 43.84, 245.6, 16.66 and 35.08 , respectively.

\section{Results}

\section{Effect of insecticides rotations}

\section{Thrips population}

The numbers of thrips/plant varied significantly among the treatments both in cool dry $(P<0.0001, \mathrm{~F}=520.26, \mathrm{df}=9$, $18)$ and hot dry $(P<0.0001, \mathrm{~F}=375.7, \mathrm{df}=9,18)$ periods. The interaction of seasons and treatments also varied significantly $(P<0.0001, \mathrm{~F}=31.89, \mathrm{df}=9,36)$. Numbers of thrips were lower at the early growth stage and increased as the season progressed during the cool dry period. During the hot dry period, this trend was not observed as the populations were generally variable. Among the sole applied insecticides, fewer numbers of thrips were counted on imidacloprid and spinetoram treatments, both in cool dry (Fig. 1) and hot dry periods (Fig. 2). Numbers of thrips were significantly higher on the untreated check and $\lambda$-cyhalothrin treatment in both cool dry (Fig. 1) and hot dry periods (Fig. 2).

Insecticides applied in different sequences resulted in varied number of thrips. The lowest number of thrips was recorded from imidachloprid-profenofos-spinetoram- $\lambda$ cyhalothrin(I-P-S-L) treatment followed by spinetoramimidacloprid-profenofos- $\lambda$-cyhalothrin(S-I-P-L) and profenofos- $\lambda$-cyhalothrin-imidacloprid-spinetoram (P-L-I-S) treatments in cool dry and hot dry periods, respectively (Figs. 1 and 2). On the other hand, the highest number of thrips was recorded on profenofos- $\lambda$-cyhalothrinimidacloprid-spinetoram (P-L-I-S) and imidacloprid- 
Fig. 1 Number of thrips on onion treated with selected insecticides as sole and in rotations during the cool dry period at Melkassa, Ethiopia, 2016/17. Error bars show SEs. $\mathrm{L}=\lambda$-cyhalothrin, $\mathrm{I}=$ Imidacloprid, $\mathrm{P}=$ Profenofos, $\mathrm{S}=$ Spinetoram

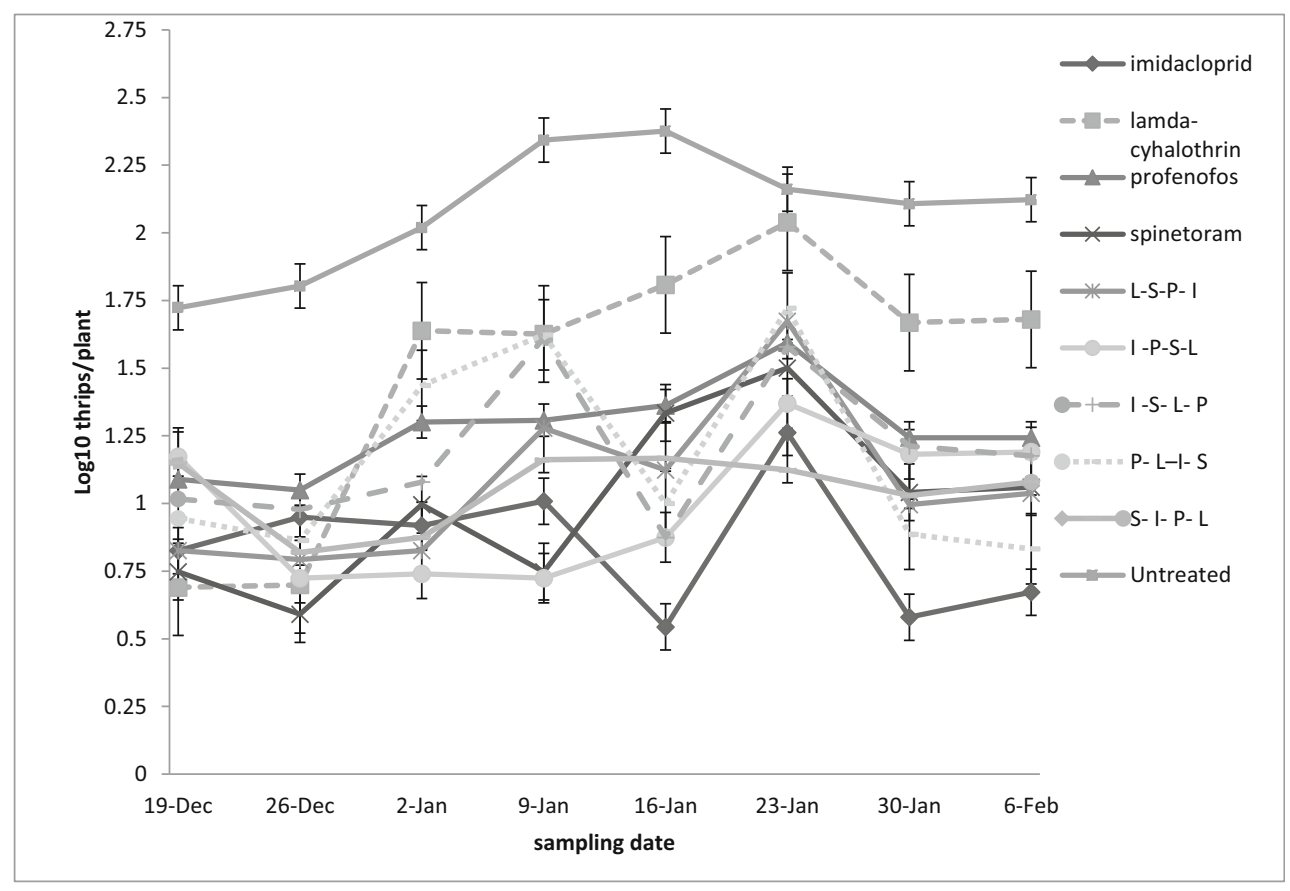

spinetoram- $\lambda$-cyhalothrin-profenofos (I-S-L-P) in cool dry and hot dry periods, respectively (Figs. 1 and 2).

\section{Yield}

All the tested insecticides, except lambda cyhalothrin applied sole or in rotation gave significantly higher marketable yields than the untreated check in both cool dry $(P<0.0001, \mathrm{~F}=$ 13.7, $\mathrm{df}=9,18)$ and hot dry $(P=0.0002, \mathrm{~F}=7.33, \mathrm{df}=9$,
18) periods. The highest marketable yield was obtained from sole applied imidacloprid in both cool dry and hot dry periods while the lowest yield across seasons was obtained in lambda cyhalothrin and untreated control (Table 2).

\section{Economic returns}

The highest net return was obtained from sole applied imidacloprid (US\$ 9856.87) followed by the rotational
Fig. 2 Number of thrips on onion treated with selected insecticides as sole and in rotations during the hot dry period at Melkassa, 2017. Error bars show SEs. $L=\lambda$ cyhalothrin, $\mathrm{I}=$ Imidacloprid, $\mathrm{P}=$ Profenofos, $\mathrm{S}=$ Spinetoram

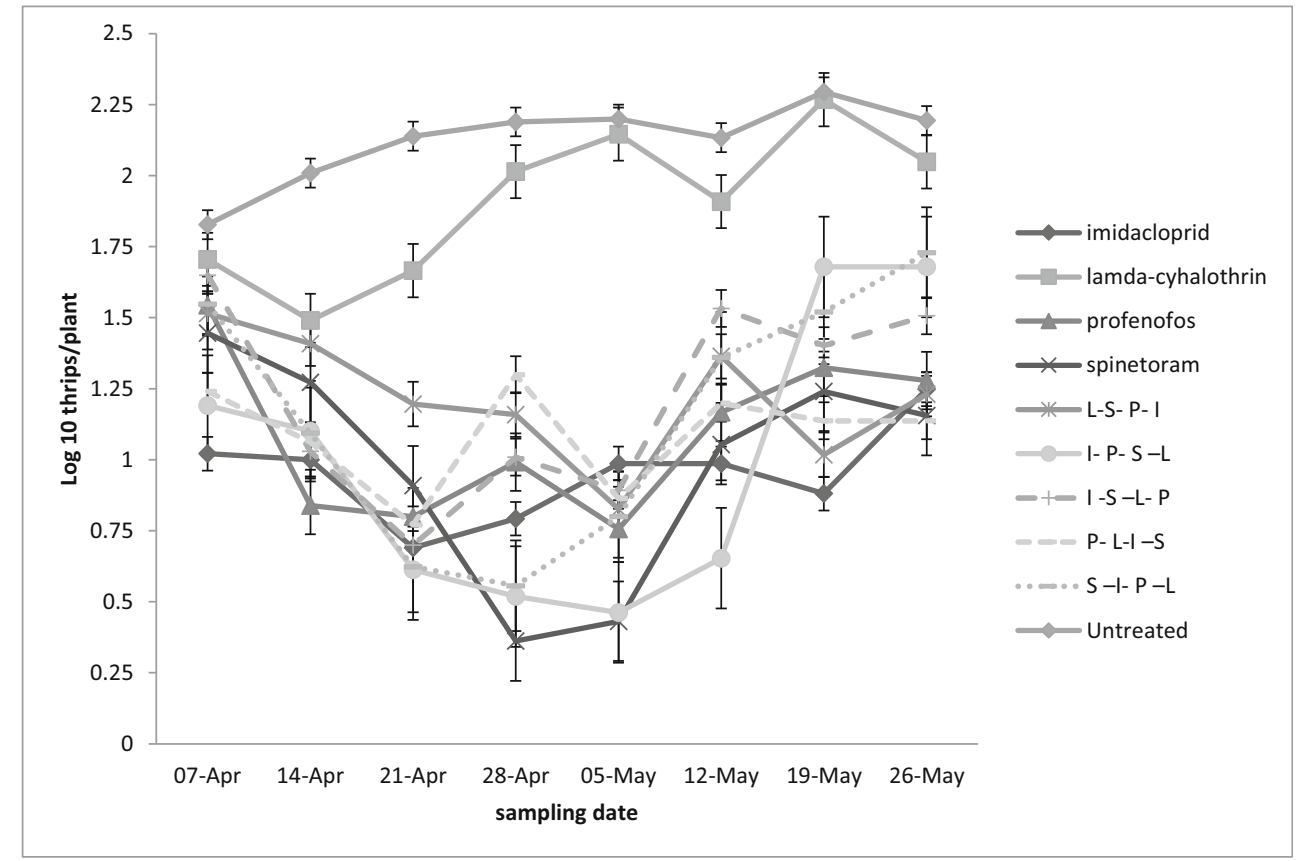


Table 2 Marketable onion bulb yield and partial economic analysis of onion treated with selected insecticides as sole and in rotations during the cool dry and hot dry periods at Melkassa Research Center, Ethiopia, 2016/17

\begin{tabular}{|c|c|c|c|c|c|c|}
\hline \multirow[b]{2}{*}{ Treatment } & \multicolumn{3}{|c|}{ Marketable Yield (tons/ha) } & \multicolumn{3}{|l|}{ Partial economic analysis } \\
\hline & Cool dry & Hot dry & Mean & Gross Return (US\$/ha) & Cost of plant Protection (US\$/ha) & Net return (US\$/ha) \\
\hline imidacloprid & $30.33^{\mathrm{a}}$ & $27.65^{\mathrm{a}}$ & $28.99^{\mathrm{a}}$ & $10,109.47$ & 252.60 & 9856.87 \\
\hline$\lambda$-cyhalothrin & $19.38^{\mathrm{d}}$ & $19.01^{\mathrm{bc}}$ & $19.19^{\mathrm{d}}$ & 6731.46 & 245.56 & 6486.10 \\
\hline profenofos & $25.30^{\mathrm{bc}}$ & $22.09^{\mathrm{b}}$ & $23.70^{\mathrm{bc}}$ & 8313.48 & 308.75 & 8004.73 \\
\hline spinetoram & $26.29^{\mathrm{b}}$ & $22.71^{\mathrm{ab}}$ & $24.50^{\mathrm{bc}}$ & 8594.11 & 395.77 & 8198.34 \\
\hline L- S-P- I & $23.33^{\mathrm{bc}}$ & $22.22^{\mathrm{b}}$ & $22.78^{\mathrm{bc}}$ & 7990.76 & 300.66 & 7690.10 \\
\hline I- P-S -L & $26.79^{\mathrm{b}}$ & $24.44^{\mathrm{ab}}$ & $25.60^{\mathrm{b}}$ & 8979.96 & 300.66 & 8679.30 \\
\hline I- S- L- p & $21.60^{\mathrm{cd}}$ & $21.35^{\mathrm{b}}$ & $21.40^{\mathrm{c}}$ & 7506.69 & 300.66 & 7206.03 \\
\hline P- L-I- S & $24.32^{\mathrm{bc}}$ & $23.64^{\mathrm{ab}}$ & $23.98^{\mathrm{bc}}$ & 8411.70 & 300.66 & 8111.04 \\
\hline S- I -P -L & $23.15^{\mathrm{bc}}$ & $24.32^{\mathrm{ab}}$ & $23.74^{\mathrm{bc}}$ & 8327.50 & 300.66 & 8026.85 \\
\hline untreated & $18.89^{\mathrm{d}}$ & $15.92^{\mathrm{c}}$ & $17.4^{\mathrm{d}}$ & 6103.57 & 0 & 6103.57 \\
\hline $\mathrm{CV}$ & 6.8 & 9.14 & 8.0 & & & \\
\hline RMSE & 1.63 & 2.04 & 1.85 & & & \\
\hline
\end{tabular}

In a column, means followed by the same letter(s) are not significantly difference at $5 \%$ level of probability by Student Newmans Keul's (SNK) test. $\mathrm{L}=\lambda$-cyhalothrin, $\mathrm{I}=$ Imidacloprid, $\mathrm{P}=$ Profenofos, $\mathrm{S}=$ Spinetoram, $\mathrm{Ha}=$ hectare, $\mathrm{Kg}=$ kilogram

application of imidacloprid-profenofos-spinetoram- $\lambda$ cyhalothrin treatment (I-P-S-L) (US\$ 8679.3), while lowest net returns were obtained from $\lambda$-cyhalothrin (US\$ 6486.1) and untreated control (US\$ 6103.57) (Table 2).

\section{Effect of surfactant on efficacy of selected insecticides}

\section{Thrips population}

The thrips populations were significantly different among the treatments both in hot dry $(P<0.0001, \mathrm{~F}=35.2, \mathrm{df}=7,16)$ and cool dry $(P<0.0001, \mathrm{~F}=278.7, \mathrm{df}=7,16)$ periods. Also, the interaction between seasons and treatments varied significantly $(P<0.0001, \mathrm{~F}=14.04$, df 7,28$)$. A significantly higher number of thrips was counted on untreated check and surfactant alone treatments, both in hot dry and cool dry periods (Figs. 3 and 4). The insecticide dimethoate applied with surfactant resulted in a significantly lower number of thrips than without surfactant in both periods (Figs. 3 and 4). On the other hand differences with and without surfactant in the insecticide spinetoram and imidacloprid were not significant, although thrips number tended to be lower in surfactant added treatment than the corresponding without surfactant treatments (Figs. 3 and 4). The interactions between insecticides and surfactant was significant in cool dry period $(P<0.0001$, $\mathrm{F}=15.81, \mathrm{df}=3,14)$, but not significant in hot dry period $(P=0.32, \mathrm{~F}=1.26, \mathrm{df}=3,14)$. However, the combined analysis of the two periods indicated that the interaction between surfactant and insecticides was significant $(P=0.0005, \mathrm{~F}=$ $8.00, \mathrm{df}=3,30)$.

\section{Yield}

Generally, significantly lower yield was obtained from the untreated check and surfactant alone treatments than the rest of the treatments both in hot dry $(P=0.0002, \mathrm{~F}=9.46, \mathrm{df}=7$, $14)$ and cool dry $(P<0.0001, \mathrm{~F}=11.33, \mathrm{df}=7,14)$ periods (Table 3). Higher marketable bulb yield was obtained from imidacloprid insecticide applied with surfactant than without. Surfactant added imidacloprid followed by spinetoram resulted in the highest yields (Table 3).

\section{Economic returns}

Higher net returns were obtained from insecticides applied with surfactant than without. The maximum net return was obtained from surfactant added imidacloprid (US\$ 9513.1). The lowest net returns were obtained from surfactant alone treatment (US\$ 6619.17) and untreated control (US\$ 6640.26) (Table. 3).

\section{Discussion}

Different classes of insecticides may have different performances because of their different inherent toxicities to insects as well as evolving resistance due to over dependence on a single insecticide product (Nault and Shelton 2010). Most of the ineffective insecticides are broad spectrum and have been in use in Ethiopia for over three decades. Vegetable growers in Ethiopia similar to farmers in several African countries rely on one effective product for the control of a particular pest 
Fig. 3 Number of thrips on onion treated with selected insecticides with and without surfactant in hot dry period, 2016. Different letters above bars denote significant differences between treatments at $5 \%$ level of probability by Student Newmans Keul's (SNK) test

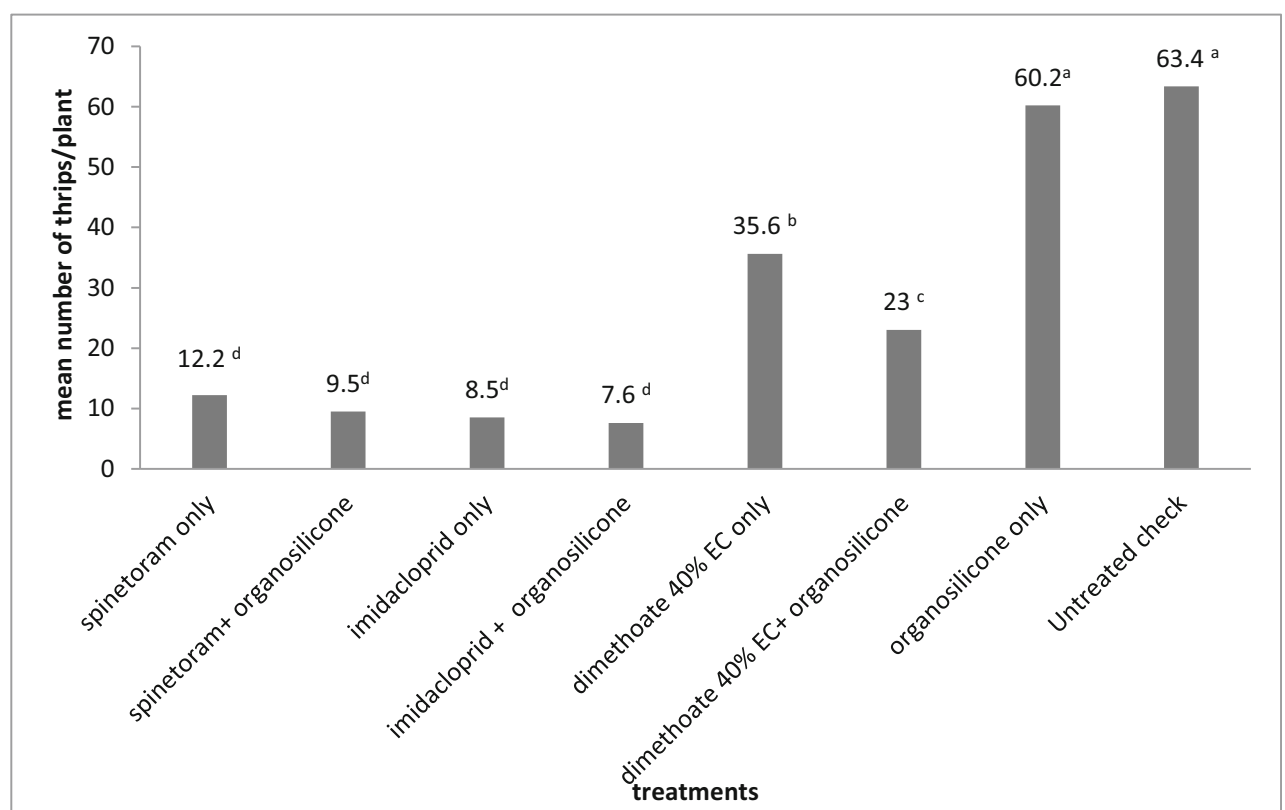

(Tebkew and Getachew 2015; Belay et al. 2017). This practice poses a high selection pressure, which may result in the development of pesticide resistant population nullifying the controlling capacity of the product. Several examples of such cases have been reported (Tabashnik et al. 2009; Gao et al. 2012).

The study showed that sole application of the systemic insecticide imidacloprid and translaminar insecticide spinetoram were more effective than sole applied contact insecticides profenofos and $\lambda$-cyhalothrin. This could be due to the differences in the mode of action and /or possible presence of resistant thrips populations to one or more of the insecticides. In addition, because of their translocation to all tissues of the treated plant (Sanchez-Bayo et al. 2013) systemic insecticides such as imidacloprid showed effective control of sucking insects compared with contact insecticides such as profenofos $50 \mathrm{EC}$ and $\lambda$-cyhalothrin $2.5 \mathrm{EC}$ on cotton (Ahmed et al. 2014).

Deploying resistance management program, among others, by sequential application of insecticides with different mode of action is useful for sustainable use of insecticides in the IPM of thrips on onion (Gholam and Sadeghi 2016). The sequential application of different insecticides resulted in a lower number of thrips per plant than the sole application of a particular insecticide. The insecticides spinetoram and imidacloprid were very effective in reducing thrips number
Fig. 4 Number of thrips on onion treated with selected insecticides with and without surfactant in cool dry period, 2016/2017. Different letters above bars denote significant differences between treatments at 5\% level of probability by Student Newmans Keul's (SNK) test

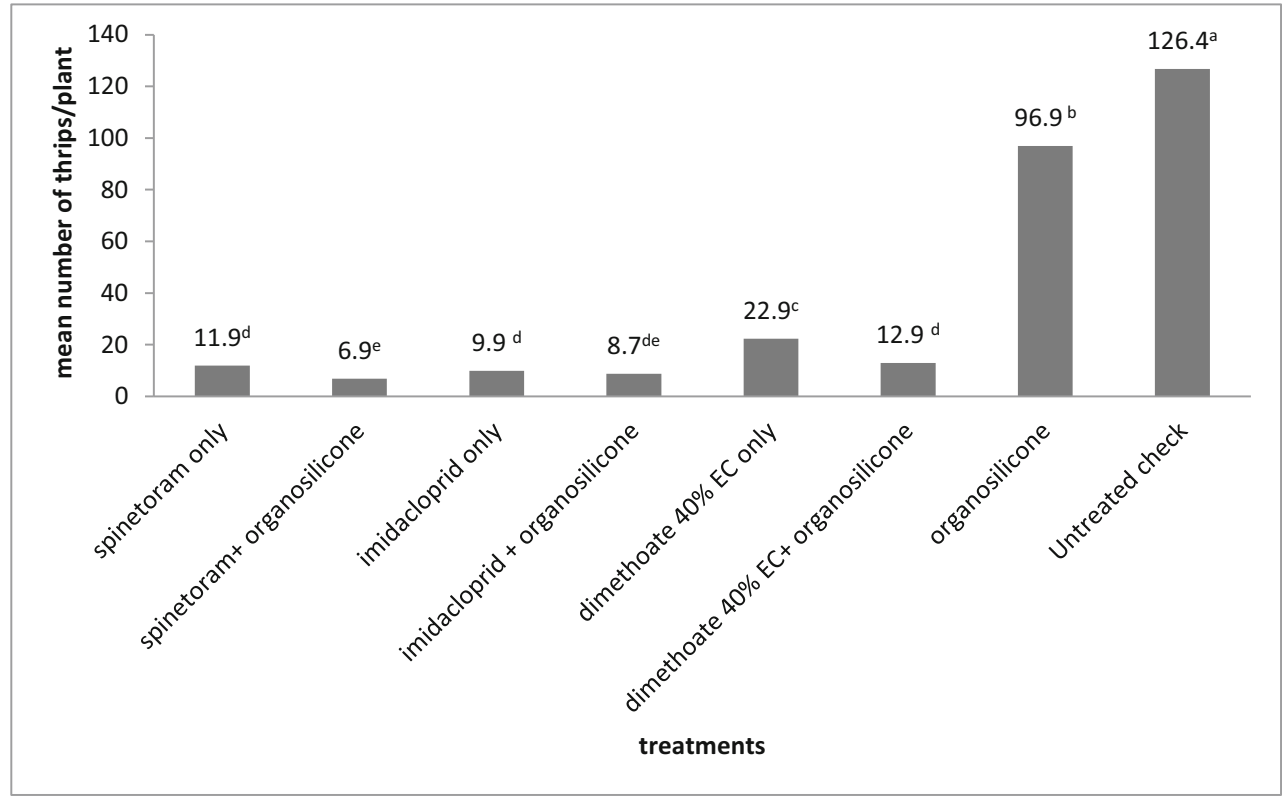


Table 3 Marketable yield and partial economic analysis of onion treated with selected insecticides with and without surfactant in hot dry and cool dry periods, 2016/17

\begin{tabular}{|c|c|c|c|c|c|c|}
\hline \multirow[t]{2}{*}{ Treatments } & \multicolumn{3}{|c|}{ Marketable yield(tons/ha) } & \multicolumn{3}{|l|}{ Partial economic analysis } \\
\hline & Hot dry & Cool dry & Mean & Gross return (US\$/ha) & Plant protection Cost (US\$/ha) & Net profit (US\$/ha) \\
\hline spinetoram only & $23.29^{\mathrm{abc}}$ & $26.54^{\mathrm{ab}}$ & $24.92^{\text {bcd }}$ & 8741.43 & 346.296 & 8395.14 \\
\hline spinetoram+ organosilicone & $25.80^{\mathrm{ab}}$ & $29.259^{\mathrm{a}}$ & $27.53^{\mathrm{ab}}$ & 9656.97 & 591.85 & 9065.12 \\
\hline imidacloprid only & $22.67^{\mathrm{c}}$ & $23.33^{\mathrm{bc}}$ & $23.00^{\mathrm{d}}$ & 8067.94 & 221.02 & 7846.92 \\
\hline imidacloprid + organosilicone & $26.74^{\mathrm{a}}$ & $30.25^{\mathrm{a}}$ & $28.45^{\mathrm{a}}$ & 9979.69 & 466.58 & 9513.11 \\
\hline dimethoate only & $23.69^{\mathrm{abc}}$ & $24.94^{\mathrm{ab}}$ & $24.11^{\mathrm{cd}}$ & 8457.3 & 239.42 & 8217.88 \\
\hline dimethoate + organosilicone & $24.98^{\mathrm{ab}}$ & $28.39^{\mathrm{ab}}$ & $26.68^{\mathrm{abc}}$ & 9358.81 & 484.98 & 8873.83 \\
\hline organosilicone only & $20.21^{\mathrm{cd}}$ & $19.63^{\mathrm{cd}}$ & $19.92^{\mathrm{e}}$ & 6987.53 & 368.36 & 6619.17 \\
\hline Untreated check & $19.59^{d}$ & $18.27^{\mathrm{d}}$ & $18.93^{\mathrm{e}}$ & 6640.26 & 0 & 6640.26 \\
\hline $\mathrm{CV}$ & 6.09 & 9.05 & 8.66 & & & \\
\hline RMSE & 1.42 & 2.27 & 2.09 & & & \\
\hline
\end{tabular}

In a column, means followed by the same letter(s) are not significantly different at 5\% level of probability by Student Newmans Keul's (SNK) test

when the infestation was high during $5^{\text {th }}$ and 6 th application times. The less effective insecticide $\lambda$-cyhalothrin appeared to perform better when applied during low infestation level in the early and late crop growth stages. Nault and Shelton (2012) reported effective control of thrips with the insecticide Radiant (spinoteram) when applied during periods of high thrips population in a sequential insecticides application program. In a different study, Reitz (2014) also found effective control of thrips with the insecticide carbamate (Lannate) when applied at an early growth stages and with the insecticide Radiant (spinoteram) when applied at 3rd through the 8th application periods.

The tendency of thrips to congregate between new onion leaves, deep within the onion leaf axils, provides them with protection from spray coverage. In addition to this, the leaf surface of the onion is waxy and smooth which is barrier to adhere and spread the insecticide properly in the target group (Gangwar et al. 2016). This problem can be minimized by using surfactants (adjuvants) with insecticides as they could improve crop leaf penetration, and/or modify droplet sizes (Nansen et al. 2013). The current study showed that adding a penetrating surfactant improved the efficacy of dimethoate insecticide compared to without a penetrating surfactant in both seasons. Surfactants add to spinetoram and imidacloprid made small improvements, which were very effective when applied alone. Other studies have shown that use of surfactant with insecticides significantly increased the efficacy of insecticides and reduced the number of thrips per plant (Nault et al. 2013; Gangwar et al. 2016; Siebert et al. 2016).

In both experiments, treatments which effectively reduced the populations of thrips increased marketable yield compared to the untreated check. The mean marketable yield from the best performing treatments, which had the greatest effect in reducing the thrips population, increased the yield of onion with higher profitability. Many studies have reported that higher bulb yields were obtained with insecticides that reduced the density of thrips (Gachu et al. 2012; Pandey et al. 2013; Reitz 2014). Yield obtained from $\lambda$-cyhalothrin was similar to untreated control in both seasons, which had little effect on thrips population in this study. This is in agreement with reports of Nault and Shelton (2010) who reported similar thrips damage ratings in $\lambda$-cyhalothrin and untreated control. Similar to results from this study, Gangwar et al. (2016) found that the insecticides applied with surfactant reduced the severity of thrips damage and increased the bulb yield when compared with the insecticides without surfactant.

The partial economic analysis of thrips controls using insecticides indicated that the highest net returns were observed in plots sprayed with imidacloprid alone insecticides followed by the rotational application of imidacloprid-profenofosspinetoram- $\lambda$-cyhalothrin treatment (I-P-S-L) (Table 2). Similar performance was observed in surfactant added insecticides treatment. In all cases, the most effective treatments gave the highest yields and gross returns. Ullah et al. (2010) reported higher net returns from more effective insecticides Confidor200SL against $T$. tabaci on onion.

\section{Conclusion}

Performance of sole applied $\lambda$-cyhalothrin was similar to the untreated control in both seasons with the minimum net return. On the other hand, imidacloprid was effective in reducing thrips numbers and increased profits as compared to other effective insecticides such as spinetoram. However, sole application of one effective insecticide is not recommended due to the risks of resistance development to the insecticide in thrips population. The sequential application of spinetoram 
and imidacloprid with less effective $\lambda$-cyhalothrin and profenofos by mixing with adjuvants is recommended for control of thrips as an integral component of thrips IPM in the CRV of Ethiopia. Further research with the purpose of assessing the effect of different adjuvants on improving the efficacy of registered insecticides for the control of thrips in Ethiopia is suggested.

Acknowledgments This research was funded by the Ethiopian Ministry of Education. We acknowledge Melkassa Agricultural Research Center, Ethiopia, for providing experimental land and the research and technical staff of Melkassa Agricultural Research Center, Department of Entomology for their unreserved technical support during the study.

\section{Compliance with ethical standards}

Conflict of interests The study does not have any conflict of interests.

Open Access This article is licensed under a Creative Commons Attribution 4.0 International License, which permits use, sharing, adaptation, distribution and reproduction in any medium or format, as long as you give appropriate credit to the original author(s) and the source, provide a link to the Creative Commons licence, and indicate if changes were made. The images or other third party material in this article are included in the article's Creative Commons licence, unless indicated otherwise in a credit line to the material. If material is not included in the article's Creative Commons licence and your intended use is not permitted by statutory regulation or exceeds the permitted use, you will need to obtain permission directly from the copyright holder. To view a copy of this licence, visit http://creativecommons.org/licenses/by/4.0/.

\section{References}

Ahmed S, Nisar MS, Shakir MM, Imran M, Iqbal K (2014) Comparative efficacy of some neonicotinoids and traditional insecticides on sucking insect pests and their natural enemies on bt-121 cotton crop. J Animal Plant Sci 24(2):660-663

Banchiamlak N, Ferdu A, Yibirh B (2012) Management of thrips, Thrips tabaci (L.) (Thysanoptera: Thripidae) on onions with synthetic insecticides and detection of resistance in the Rift Valley of Ethiopia. Paper presented at the $19^{\text {th }}$ Annual Conference of the Plant Protection Society of Ethiopia (PPSE). December 27-28, 2012, Addis Ababa, Ethiopia

Bekele E, Ferdu A, Tsedeke A (2006) Facilitating the implementation and adoption of IPM in Ethiopia. Proceedings of a planning workshop. EARO, Nazerath, Ethiopia

Belay M, Arthur T, Mol PJ, Oosterveer P (2017) Pesticide use practices among smallholder vegetable farmers in Ethiopian central Rift Valley. Environ Dev Sustain 19(1):301-324

Bielza P, Quinto V, Contreras J, Torne M, Martın A, Espinosa PJ (2007) Resistance to spinosad in the western flower thrips, Frankliniella occidentalis (Pergande), in greenhouses of South-Eastern Spain. Pest Manag Sci 63:682-687

CSA (Central Statistical Authority) (2016) Agricultural sample survery 2015/16 (2008 E.C.). Report on area, production and farm management practice of Belg season crops for private peasant holdings, vol 5. Addis Ababa, Ethiopia. Statistical Bulletin, p 578
Desalegne L, Shimeles A (2003) Research experiences in onion production. Research report number, 55. EARO, Addis Ababa Ethiopia

FAOSTAT (Food and Agriculture Organization Statistics) (2012) Food and agriculture organization statistics data base, agricultural production indices. Rome, Italy

Gachu SM, Muthomi JW, Narla RD, Nderitu JH, Olubayo FM, Wagacha JM (2012) Management of thrips (Thrips tabaci) in bulb onion by use of vegetable intercrops. Int J Agric Sci 2: 393-402

Gangwar RK, JAT GS, Rathore SS, Sharma RK (2016) Effect of surfactant on the efficacy of insecticides against onion thrips, Thrips tabaci. Indian J Agric Sci 86(6):757-761

Gao Y, Lei Z, Reitz SR (2012) Western flower thrips resistance to insecticides: detection, mechanisms and management strategies. Pest Manag Sci 68(8):1111-1121

Gholam Z, Sadeghi A (2016) Management strategies for western flower thrips in vegetable greenhouses in Iran: a review. Plant Prot Sci 52(2):87-98

Gill HK, Garg H (2014) Environmental impacts and management strategies. In Solenski S, Larramenday ML (eds) Pesticides-toxic-aspects/ pesticides-environmental-impacts-and management-strategies, pp $187-230$

Gill HK, Garg H, Gill AK, Gillett-kaufman JL, Nault BA (2015) Onion Thrips (Thysanoptera: Thripidae) biology, ecology and management in onion production systems. J Integr Pest Manag $6(1): 1-9$

Herron G, James TM, Rophail J, Mo J (2008) Australian population of onion thrips, Thrips tabaci Lindeman (Thysanoptera: Thripidae), are resistant to some insecticides used for their control. Aust J Entomol 47:361-364

MoANR (Ministry of Agriculture and Natural Resources) (2017) Plant health regulatory directorate. List of Registered Pesticides, Addis Ababa

Nansen C, James T, Smith RD (2013) The performance of insecticides. Trdan S (eds) Insecticides development of safer and more effective technologies, pp195-231. https://doi.org/10.5772/3356

Nault BA, Shelton AM (2010) Impact of insecticide efficacy on developing action thresholds for Pest management: a case study of onion Thrips (Thysanoptera: Thripidae) on onion. J Econ Entomol 103(4): $1315-1326$

Nault BA, Shelton AM (2012) Guidelines for managing onion thrips on onion. Veg edge. Cornell University, cooperative extension. Regional Vegetable Programs 8:14-17

Nault BA, Hsu C, Hoepting C (2013) Consequences of co-applying insecticides and fungicides for managing Thrips tabaci (Thysanoptera: Thripidae) on onion. Pest Manag Sci 69(7): 841-849

Pandey S, Singh BK, Gupta RP (2013) Effect of neem based botanicals, chemicals and bio-insecticides for the management of thrips in onion. Indian J Agric Res 47(6):545-548

Reitz SR (2014) Onion Thrips (Thysanoptera: Thripidae) and their management in the treasure valley of the pacific northwest. Fla Entomol 97(2):349-354

Sanchez-Bayo F, Henk A, Tennekes KG (2013) Impact of systemic insecticides on organisms and ecosystems. Insecticides Development of Safer and More Effective Technologies. https://doi.org/10.5772/ 52831

SAS (2003) In SAS user's guide: statistical analysis Systems, Version 9.1.3. SAS Institute, Inc, Cary

Shelton AM, Nault BA, Plate J, Zhao JZ (2003) Regional and temporal variation in susceptibility to $\lambda$-cyhalothrin in onion thrips, Thrips tabaci (Thysanoptera: Thripidae), in onion fields in New York. J Econ Entomol 96(6): 1843-1848 
Shelton AM, Zhao JZ, Nault BA, Plate J, Musser FR, Larentzaki E (2006) Patterns of insecticide resistance in onion thrips (Thysanoptera: Thripidae) in onion fields in New York. J Econ Entomol 99(5): 1798-1804

Siebert MW, Nolting SP, Dripps JE, Walton L, Cook DR, Stewart SD, Gore J, Catchot AL, Lorenz GM, Leonard BR, Herbert A (2016) Efficacy of spinetoram against thrips (Thysanoptera: Thripidae) in seedling cotton, Gossypium hirsutum L. J Cotton Sci 319:309319

Tabashnik BE, Van Rensburg JBJ, Carrière Y (2009) Field-evolved insect resistance to Bt crops: definition, theory, and data. J Econ Entomol 102(6):2011-2025

Tadele S, Amin M (2014) The importance and management option of onion thrips, T. tabaci (L) (thysanoptera : thripidae ) in Ethiopia : a review. Adv Res Agric Vet Sci 1(3):95-102
Tadele S, Mulugeta N (2014) Evaluation of insecticides and botanicals against onion thrips, Thrips tabaci (L.) (Thysanoptera : Thripidae). Entomol Appl Sci 1(2):26-30

Tebkew D, Getachew T (2015) Small-scale vegetable producers' perception of pests and pesticide uses in east Shewa zone, Ethiopia. Int J Pest Manag 61(3):212-219

Ullah F, Maraj UM, Abid F, Muhammad QS, Shahid S (2010) Population dynamics and chemical control of onion Thrips (Thrips tabaci, Lindemann). Pak J Zool 42(4):401-406

Publisher's note Springer Nature remains neutral with regard to jurisdictional claims in published maps and institutional affiliations. 